\title{
Impact of High-Speed Lines in Relation to Very High Frequency Air Services
}

\author{
Andrés López-Pita and Francesc Robusté \\ CENIT (Center for Innovation in Transport) \\ Technical University of Catalonia
}

\begin{abstract}
The Madrid-Barcelona air route constitutes one of the main aerial routes in the European corridor in terms of traffic demand (4.2 million passengers in 2003). To deal with such a high demand, three airline companies (Iberia, Air Europa, and Span Air) globally offer more than 60 flights per day either way.

Currently, the construction of a high-speed railway line between the two cities is under way. The line is expected to come into commercial service by 2007, covering the whole of the $625 \mathrm{~km}$ between the cities.

This article analyzes the impact that high-speed railway services have on air traffic demand. The results are then compared with real data corresponding to the Paris-London line, on the occasion of the launch of the commercial service of the high-speed Eurostar train.
\end{abstract}




\section{Introduction}

In the past decade (1990-2000) the demand for air transport in Spain has increased significantly. A thorough examination of the changes in air traffic in the Madrid-Barcelona route, one with the greatest demand within the Iberian peninsula, is a sufficient indicator of this growth. In fact, in 1990 the flow of air passengers between the two cities was 2 million persons, while last year, this figure reached 4.2 million passengers - an average annual growth of 6.4 percent.

Internationally, the above-mentioned figures place Spain in the vanguard of European air sectors with the greatest air traffic demand (Table 1).

\section{Table 1. Main Passenger Air Traffic Routes Within the Main European Countries (2001)}

\begin{tabular}{|c|c|c|}
\hline Country & Route & $\begin{array}{c}\text { Passenger Air Traffic } \\
\text { (in millions) }\end{array}$ \\
\hline Germany & Frankfurt-Berlin & 1.6 \\
& Frankfurt-Munich & 1.5 \\
\hline Spain & Madrid-Barcelona & 4.0 \\
& Barcelona-Palma de Mallorca & 1.6 \\
\hline France & Paris-Nice & 3.0 \\
& Paris-Toulouse & 2.9 \\
\hline Great Britain & London-Glasgow & 2.7 \\
& London-Edinburgh & 2.6 \\
\hline Italy & Rome-Milan & 3.4 \\
\hline
\end{tabular}

Source: Original chart using data from the Institute of Air Transport (ITA).

The Madrid-Barcelona sector was opened to air transport liberalization in 1993. Since then, two new companies, Air Europa and Span Air, have offered services along with Iberia, the only operating airline in this route before 1993 . The increase in the number of services has given rise to two important factors: (1) a significant increase in mobility in this corridor and (2) an overwhelming alteration in the modal distribution of air traffic among the three companies.

On the other hand, a new railway high-speed line is presently under construction, which, by 2005, will connect Madrid and Barcelona in two and a half hours. 
This article explores the effect of air transport liberalization and the foreseen consequences not only by air companies that operate in this corridor, but also by the new railway operator (RENFE), in the modification of the present distribution between modes of transportation demand.

\section{The Madrid-Barcelona Air Corridor (1974-1993)}

The main commercial routes that have existed for more than 25 years between the two cities can be summarized by the following data: at the beginning of the 1970s, air traffic through this corridor was approximately 900,000 passengers per year. This traffic included 78 percent businesspeople who wanted to take a round-trip on the same day.

To meet this demand, in November 1974 Iberia introduced its shuttle service, the first such service operating in Europe. This service encompassed the Anglo-Saxon concept of "first come, first served." The first air shuttle of this kind operated between Rio de Janeiro and Sao Paulo (1959), followed by a similar service established shortly thereafter between New York and Washington, D.C. (1961).

For almost 20 years, Iberia was the only airline operating the Madrid-Barcelona connection. In terms of supply, 13 flights per day in either direction were offered in 1974, while 30 flights per day were offered in 1993. Figure 1 shows that passenger traffic grew from 974,000 the first year the air shuttle service operated (1974) to $1,926,000$ passengers in 1993. It is easy to see the influence of the economy on the development of air traffic over time. In the first half of the 1980s, air service was affected by a serious economic crisis in Spain. While the year 1991 was especially difficult because of the Gulf War, air service partially recovered due to the Olympics, which were held in Barcelona the following year (1992). In short, air traffic on the Madrid-Barcelona route doubled during the period 1974-1993. 


\section{Figure 1. Evolution of Air Traffic on the Madrid-Barcelona Route} (1974-1993)

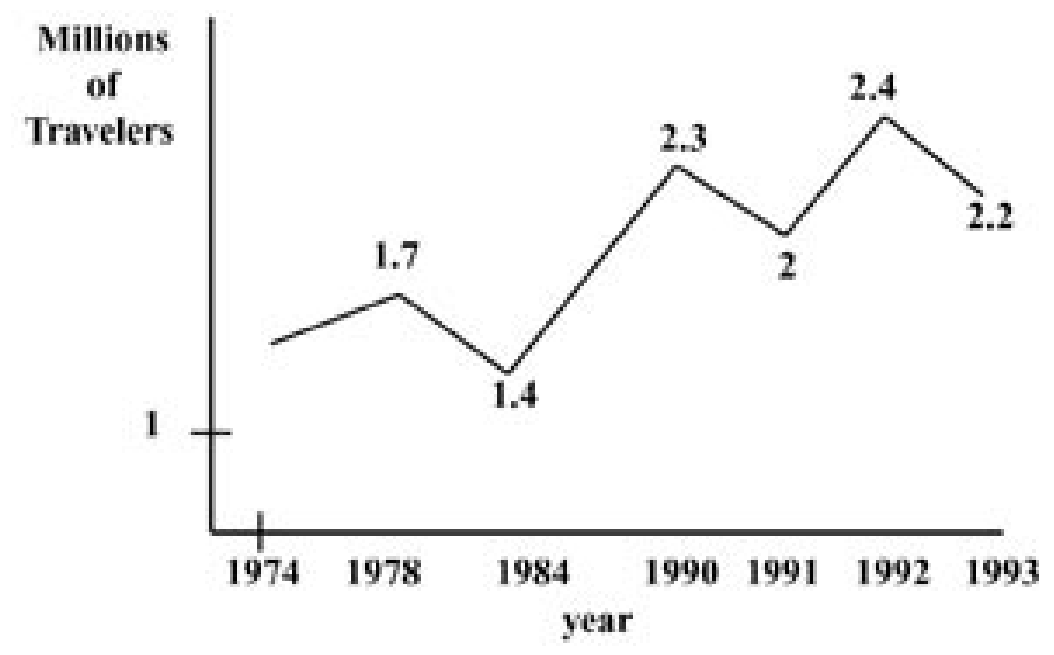

\section{Arrival of New Companies in the Madrid-Barcelona Air Shuttle}

The opening of the airline market in Europe began to take effect at the end of the 1980 s, and it came into being for the domestic market as of January 1993. For the Madrid-Barcelona corridor, this was characterized by the introduction of a new range of flights provided by two airlines that, until that time, had not operated in this sector: the first, Air Europa, began services on January 31, 1994, and the second, Span Air, on March 14, 1994. Table 2 shows the flights initially offered by each airline.

An analysis of Table 2 shows the following significant features:

- Frequency of service offered by lberia was notably higher than that offered by the other two companies. Specifically, out of a weekly total (the number of flights on Saturdays and Sundays decreases for any company) of 603 flights, Iberia offered 430 flights (71\%); Air Europa, 102 flights (14\%); and Span Air, 71 flights (12\%).

- Unlike Iberia, Air Europa and Span Air obligated passengers to reserve a seat on a given flight (despite the fact that the flight initially chosen could be changed under certain conditions). 
Table 2. Services Provided in the Madrid-Barcelona Air Shuttle (1994)

\begin{tabular}{|c|c|c|c|c|}
\hline Airline & $\begin{array}{c}\text { Frequency of } \\
\text { Service }\end{array}$ & $\begin{array}{l}\text { Type of } \\
\text { Fare }\end{array}$ & $\begin{array}{l}\text { Price Level }(€) \\
\text { (one way) }\end{array}$ & $\begin{array}{c}\text { Fare } \\
\text { Conditions }\end{array}$ \\
\hline \multirow[t]{4}{*}{ Iberia } & \multirow{4}{*}{$\begin{array}{l}\text { every } 15 \mathrm{~min} \text {. } \\
\text { on the hour } \\
\text { every } 30 \\
\text { to } 60 \mathrm{~min} \text {. } \\
\text { during } \\
\text { nonpeak } \\
\text { hours } \\
\text { regularly } \\
\text { scheduled } \\
\text { flights }\end{array}$} & Business & 114 & $\begin{array}{l}\text { No reservation } \\
\text { needed }\end{array}$ \\
\hline & & $\begin{array}{c}\text { Flexible } \\
\text { economy rate }\end{array}$ & 90 & $\begin{array}{l}\text { No reservation } \\
\text { needed }\end{array}$ \\
\hline & & $\begin{array}{l}\text { Low-hour } \\
\text { economy rate }\end{array}$ & 72 & $\begin{array}{l}9 \mathrm{am} \text { to } 4 \mathrm{pm} \\
8 \mathrm{pm} \text { to } 10 \mathrm{pm}\end{array}$ \\
\hline & & $\begin{array}{l}\text { Reduced } \\
\text { price }\end{array}$ & 58 & $\begin{array}{l}\text { Reservation } \\
\text { needed }\end{array}$ \\
\hline \multirow[t]{2}{*}{$\begin{array}{l}\text { Air } \\
\text { Europa }\end{array}$} & \multirow[t]{2}{*}{ Every $2 \mathrm{hrs}$} & $\begin{array}{c}\text { Regular } \\
\text { economy fare }\end{array}$ & 60 & $\begin{array}{l}\text { Reservation } \\
\text { required }\end{array}$ \\
\hline & & $\begin{array}{c}\text { Reduced } \\
\text { economy fare }\end{array}$ & 54 & $\begin{array}{l}\text { Bought in a } \\
\text { booklet of } \\
20 \text { flights }\end{array}$ \\
\hline \multirow[t]{3}{*}{$\begin{array}{l}\text { Span } \\
\text { Air }\end{array}$} & \multirow[t]{3}{*}{ Every 2-3 hrs } & Business & 77 & $\begin{array}{l}\text { Reservation } \\
\text { required }\end{array}$ \\
\hline & & $\begin{array}{c}\text { Regular } \\
\text { economy fare }\end{array}$ & 60 & $\begin{array}{l}\text { Reservation } \\
\text { Required }\end{array}$ \\
\hline & & $\begin{array}{l}\text { Economy fare } \\
\text { (round trip) }\end{array}$ & 51 & $\begin{array}{l}\text { Buying the } \\
\text { round-trip } \\
\text { ticket at the } \\
\text { same time }\end{array}$ \\
\hline
\end{tabular}

\section{$€=$ Euros}

- Prior to the arrival of the two new companies, lberia had a single fare of 90 euros for tourist class. Upon their addition, Air Europa and Span Air offered fares that were 33 percent lower than the existing ones, with normal fares of around 60 euros. 
With regard to the demand for air traffic, Table 3a shows the changes experienced by each airline. Note how the arrival of the new companies on the Madrid-Barcelona air shuttle route led to an increase in air traffic by almost one million passengers in its first year of operation (1994) compared to the previous year (1993).

In terms of market share, in 1994 Air Europa and Span Air each captured 15 percent of the total passenger traffic, with Iberia's share decreasing from 100 to 70 percent. Since then, Span Air has progressed the most, achieving a market share of more than 21 percent in 2002. Subsequently, Iberia's market share was 64.5 percent, and Air Europa's was 14.1 percent.

As shown in Table 3a, Iberia's market share has decreased by 35.5 percent since the arrival of the other airlines in the Madrid-Barcelona route. The impact of Air Europa and Span Air was an overall increase of 30 percent, and in the past eight years both companies (but especially the latter) have captured 5 percent more of the market share.

After examining Table 3a, it is worth exploring why Span Air has experienced such strong growth, especially in the past two years. The reasons include:

1. Ever since its entry into the sector in 1994, Span Air has increased its number of flights per day in either direction, beginning with 7 to 16 currently. In contrast, Air Europa has maintained virtually the same number of flights ( 9 and 10 flights per day in 1994 and 2002, respectively).

2. In a survey of passengers conducted in 1995 , Span Air was the most highly rated airline with respect to treatment by land and flight personnel, in-flight service, ease of boarding, seat comfort, and comfort and cleanliness on board. Seven years later, passenger ratings remain the same.

3. Span Air is considered one of the most punctual European airlines (rated number one in 2002). In addition, in February 2001 it added a commitment to punctuality by promising passengers a free ticket for any delay of more than 15 minutes in the airline's departure from Madrid or Barcelona.

4. In terms of fare levels, Span Air continues to provide the most competitively priced transport services compared to the other companies (see Table 3b).

Depending on the time of the flight, fare levels offered by Span Air even in business class are at times up to 60 percent less than those of Iberia (Table 3b). Fare differences between the two companies are also significant in economy class. 


\section{Table 3a. Passenger Air Traffic and Market Share by Airline on the Madrid-Barcelona Route (1993-2003)}

\begin{tabular}{|c|c|c|c|c|c|c|}
\hline \multirow{2}{*}{ Airline } & & \multicolumn{5}{|c|}{ Year } \\
\hline & & 1993 & 1994 & 1997 & 2001 & 2003 \\
\hline \multirow[b]{2}{*}{ Iberia } & Traffic* & 1.92 & 1.98 & 207 & 2.70 & 2.72 \\
\hline & $\begin{array}{c}\text { Market } \\
\text { share (\%) }\end{array}$ & 100 & $x$ & 67 & 67 & 64.5 \\
\hline \multirow[b]{2}{*}{ Air Eurpos } & Traffic & $\cdot$ & 0.44 & 0.44 & 0.54 & 0.59 \\
\hline & $\begin{array}{c}\text { Market } \\
\text { share (\$) }\end{array}$ & $*$ & 15 & 14 & 13.6 & 14.1 \\
\hline \multirow[b]{2}{*}{ Span Air } & Traffic ${ }^{\circ}$ & . & 0.45 & 0.55 & 0.78 & 0.90 \\
\hline & $\begin{array}{c}\text { Market } \\
\text { share (\%) }\end{array}$ & . & 15 & 18 & 19.4 & 21.6 \\
\hline \multicolumn{2}{|l|}{ Total Traffic } & 192 & 2.87 & 306 & 4.02 & 4.21 \\
\hline
\end{tabular}

${ }^{*}$ Million passengers

Source: A. López Pita using data from Iberia, Air Europa, and Span Air.

Table 3b. Airfare Levels on the Madrid-Barcelona Route (2002)

\begin{tabular}{|c|c|c|c|c|}
\hline \multirow{2}{*}{ Airline } & \multicolumn{4}{|c|}{ Fare $(\Theta)$ (One Way) } \\
\cline { 2 - 5 } & $\begin{array}{c}\text { Normal Business } \\
\text { Class }\end{array}$ & $\begin{array}{c}\text { Cheapest } \\
\text { Eusiness Class }\end{array}$ & $\begin{array}{c}\text { Normal } \\
\text { feanomy Class }\end{array}$ & $\begin{array}{c}\text { Cheapest } \\
\text { Econamy Class }\end{array}$ \\
\hline Air Europa & 157.45 & 75.45 & 136.45 & 64.45 \\
Iberia & 168.45 & 168.45 & 117 or 136 & 97 \\
Span Air & 155.45 & 65.45 & 142.45 & 35.45 \\
\hline
\end{tabular}

$€=$ Euros

Iberia's main attraction continues to be its frequency of flights, with 47 per day in either direction; that is, it has three times as many flights as Span Air. These differences are more pronounced during nonpeak hours and less so during peak hours.

\section{Madrid-Barcelona Corridor Supply and Demand}

The two largest Spanish cities, Madrid and Barcelona, form metropolitan areas of more than 5 and 3 million inhabitants, respectively. From a demographic point of view, the cities located along the corridor linking Madrid and Barcelona are Zaragoza (700,000 inhabitants), Lleida (120,000 inhabitants), and Tarragona/Reus (200,000 inhabitants) (Figure 2). 


\section{Figure 2. The Madrid-Barcelona Corridor}

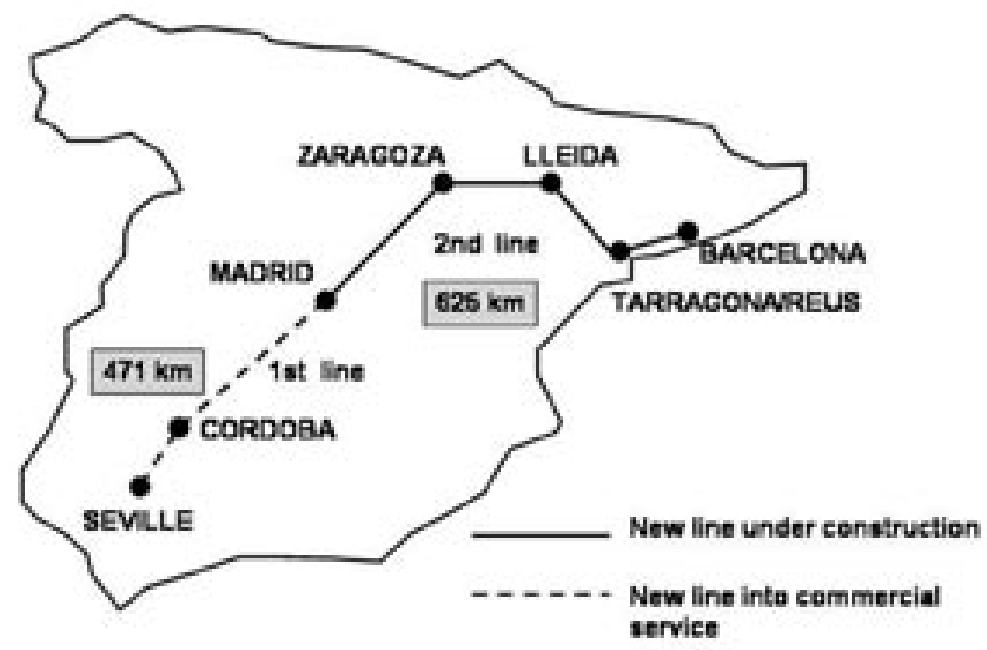

Among the transport services offered to people traveling between Madrid and Barcelona are:

- a highway infrastructure as far as Zaragoza $(325 \mathrm{~km})$ and a freeway from there to Barcelona $(296 \mathrm{~km})$

- a railway line $(692 \mathrm{~km}$ ) between Madrid and Barcelona, which is $71 \mathrm{~km}$ further than the distance by road and $212 \mathrm{~km}$ more than that by air

- air service provided by three companies between Madrid and Barcelona

Travel times offered by each mode of transport, average service frequency, and fare levels are given in Table 4. The response of demand to the services offered by each mode is air, 64 percent; private vehicle, 23 percent; railway, 8 percent; and coach, 5 percent. 
Table 4. Madrid-Barcelona Passenger Transport Services (2002)

\begin{tabular}{|l|c|c|c|c|}
\hline & \multicolumn{4}{|c|}{ Transport Mode } \\
\cline { 2 - 5 } & Air & Railway & Coach & $\begin{array}{c}\text { Private } \\
\text { Vehicles }\end{array}$ \\
\hline Traveling time (hour) & 1 & 6.5 & 7.5 & 6 \\
$\begin{array}{l}\text { Average service } \\
\text { frequency per day and } \\
\text { direction }\end{array}$ & 60 & 5 & 12 & - \\
Fare (dollars) & $\begin{array}{c}\text { Business: } \\
157.21\end{array}$ & $\begin{array}{c}\text { Business: } \\
\text { Tourist: } \\
105 / 124\end{array}$ & $\begin{array}{c}\text { Tourist: 42-16 } \\
\text { Eurobus: 30 }\end{array}$ & $\begin{array}{c}\text { Normal 22.08 } \\
\text { fetrol and } \\
\text { freeway toll: } \\
74.5\end{array}$ \\
\hline
\end{tabular}

This supply-demand analysis shows that railways play a very insignificant role in passenger services between Madrid and Barcelona. It is important to note that the existing rail line between the two cities, built in the 19th century, imposes a constraint on the commercial speed to about $106 \mathrm{~km} / \mathrm{h}$ and does not permit the journey times of even the fastest trains ( $6 \mathrm{~h} 30 \mathrm{~min}$ ) to be reduced.

\section{Construction of a New Rail Line Between Madrid and Barcelona at $350 \mathrm{~km} / \mathrm{h}$}

As discussed above, the existing Madrid-Barcelona line offers low-quality service, especially with regard to the commercial speed achieved between the two cities (for European standards) $-100 \mathrm{~km} / \mathrm{hr}$. It also comprises only about 8 percent of the distribution among all the services. Improvement of this service is not possible due to the current state of the railway lines which provide a limited turning radius in terms of railway track geometry (300 to $700 \mathrm{~m}$ ).

Difficulties on the rail route between Madrid and Barcelona, the commercial success achieved with high-speed lines operating between Madrid and Seville with standard gauge, and existing congestion problems at airports in both cities led the Spanish government to plan a new line between the country's two most important cities.

With respect to air traffic, it is important to remember that the volume of passengers at Madrid airport increased from 15 million in 1991 to 34 million in 2001, an average annual accumulative growth of 8.5 percent. Meanwhile, passenger traffic 
at Barcelona airport in the same period increased from 9 million to 20 million, averaging similar annual growth to that of the Madrid airport. It is no surprise, therefore, that the percentage of flights delayed by more than 15 minutes at both airports is almost 50 percent, with an average delay per flight of around $50 \mathrm{~min}$ utes.

Based on these data, the new line project between Madrid and Barcelona (standard gauge) will provide a railway service that is very attractive to habitual shuttle passengers. In particular, origin/destination traveling times of two and a half hours are projected.

Looking toward the future, what scenarios can be forecast for this corridor?

\section{Foreseeable Future Scenario}

An analysis of the impact of high-speed railway services on air transport demand in Europe has been the subject of many studies in the past few decades. Thus, the curve shown in Figure 3 emphasizes rail's market share compared to that of the airlines, according to how long the trip takes by land transport.

\section{Figure 3. Effect of Train Journey Time on the Proportion of Air and Rail Travelers}

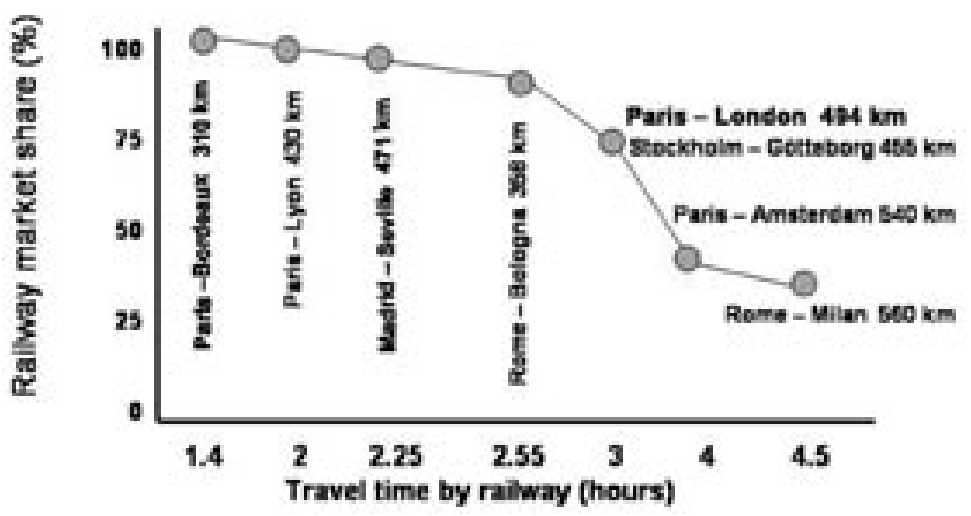

Source: UIC (International Union of Railways). 
Based on this curve shown in Figure 3, and more specifically from the experiences on the Madrid-Seville high-speed line (Table 5), it would be tempting to extrapolate the same conclusions about the operation of the new high-speed Madrid-Barcelona line.

\section{Table 5. Railway Market Share Compared to Airline Market Share on Madrid-Seville Route}

\begin{tabular}{|c|c|c|c|c|c|c|}
\hline \multirow{3}{*}{$\begin{array}{l}\text { Means of } \\
\text { Transport }\end{array}$} & \multicolumn{6}{|c|}{ Market Share ( $\%$ ) } \\
\hline & \multirow{2}{*}{$\begin{array}{c}1992 \\
\text { (before } \\
\text { high-speed } \\
\text { None) }\end{array}$} & \multicolumn{5}{|c|}{ with High-speed line } \\
\hline & & 1994 & 1996 & 1998 & 2000 & 2003 \\
\hline Air & 71 & 20.1 & 18.4 & 179 & 166 & 15.9 \\
\hline Rail & 29 & 79.9 & 81.6 & 82.1 & 83.4 & 84.1 \\
\hline
\end{tabular}

Source: RENFE and Iberia.

The distribution by means of transport on the Madrid-Seville route corresponds to a railway travel time between the two cities of two and a half hours, precisely the same amount of time forecast for the Madrid-Barcelona route. Thus, we could initially estimate that the high-speed railway on the Madrid-Barcelona route could also have a market share of more than 80 percent compared to the airlines.

An evaluation of what the potential market share might be has been carried out using the forecasting models that are usually applied in Europe. The need for a more precise estimate essentially comes from the existence of two important elements that differentiate this line from the Madrid-Seville sector:

1. different attributes of the competition between different means of transport in both corridors, as seen in Figure 4, and

2. foreseeable generation of less traffic on the Madrid-Barcelona route since it is primarily a commercial route.

On the other hand, it is important to take into account that present air services between Madrid and Barcelona are noticeably different from that existing in other sectors where a high-speed line was also built (Figure 4). Consequently, for this Spanish scenario, the average waiting time between two flights is only 20 minutes 


\section{Figure 4. Scenario of Competition Between Means of Transport on the Madrid-Seville and Madrid-Barcelona Routes}

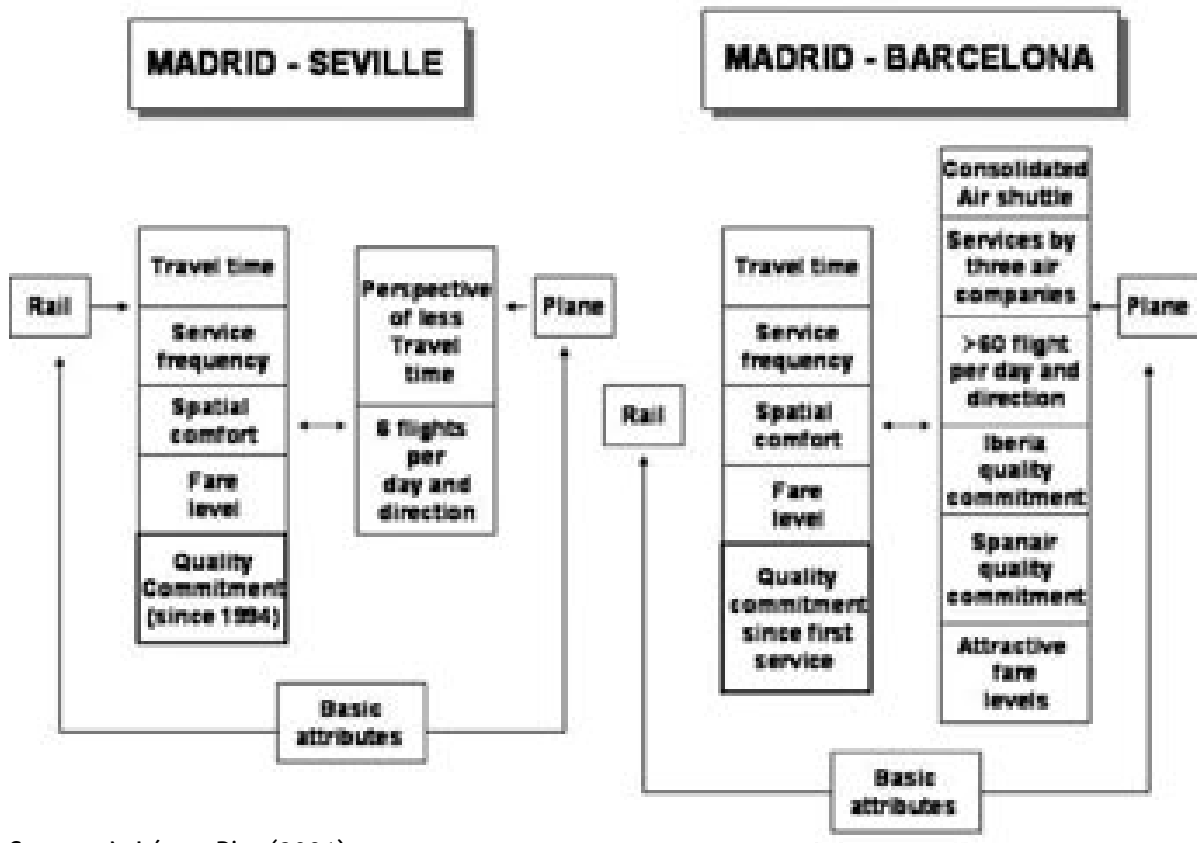

Source: A. López-Pita (2001).

Demand for railway transport has been estimated based on the use of the pricetime model to determine the distribution between the two means of transport and based on a gravitational model for the evaluation of the traffic generated.

The price-time model provides a means of calculating the share of traffic of the different modes as a fraction of the total traffic. The model elaborated between 1967 and 1973 by C. Abraham and J. D. Blanchet is based on the assumption that passengers choose between two different modes in relation to the value they attach to time, cost, and journey time features of each of the modes. Thus, the user selects the mode with the lowest generalized cost in relation to this value of time.

Time value represents the price (in dollars per hour) a traveler agrees to spare one hour of his or her journey. The higher the number, the more the time is valorised and, therefore, the more inclined the traveler will be to use the fastest transportation mode, irrespective of the price. On the other hand, a traveler whose time value is low will consider the price criteria before the speed criteria. 
Analytically, generalized costs for traveler $\mathrm{j}$ of two modes are:

Mode $1 \quad C g_{1}=P_{1}+h_{j} T_{1}$

Mode $2 \quad C g_{1}=P_{2}+h_{j} T_{2}$

where:

$P_{i} \quad$ is the price of the journey including access/egress cost

$T_{i} \quad$ indicates total trip time (travel time from A to B with mode $i$; access/time from $A$ with mode $i$ (air to rail) to the airport or the station, including terminal time; egress time from $B$ with mode $i$ (air or rail) from the airport or the station; time of waiting between two flights

$C g_{i}$ equals generalized cost (expressed in dollars)

$h_{j}$ is time value

Figure 5 shows the choice between air-auto-high-speed rail according to the respective generalized costs.

\section{Figure 5. Price-Time Model}

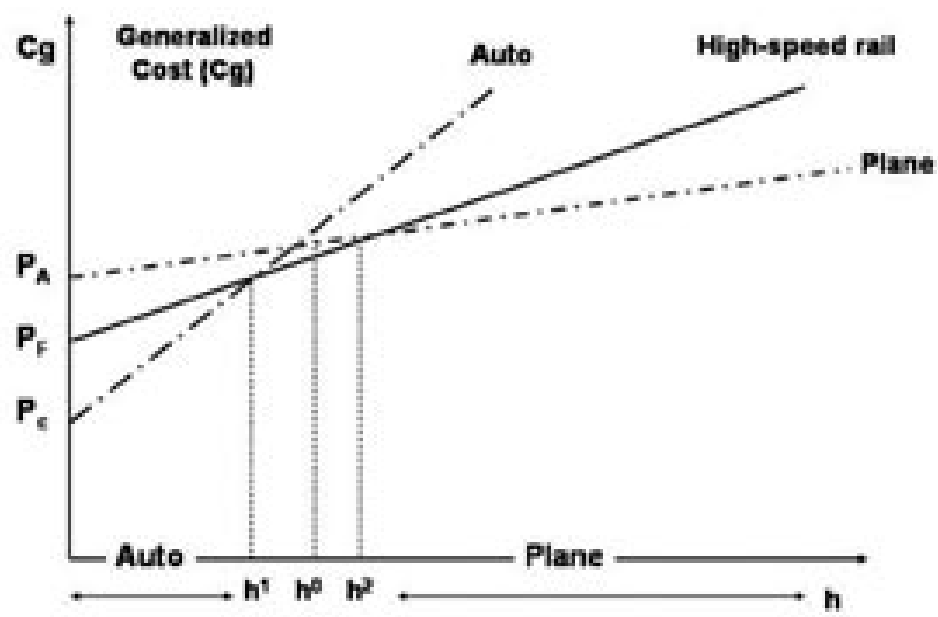

Value of time 
Passenger traffic estimates between Madrid and Barcelona were based on the following assumptions:

- Auto: Fare level similar to the current level (\$74.5, petrol and freeway toll)

- Airplane: Fare level similar to the current level (average price equivalent to $\$ 90$ by passenger

- Railway: Fare level similar to the Madrid-Seville line (average price equivalent to $\$ 0.12(\mathrm{Vkm})$

- Value of travel time in $2002(\$)$

\begin{tabular}{|l|c|c|c|}
\hline Mobility & Auto & Airplane & High-Speed Railway \\
\hline Obligatory & 14 & 40 & 30 \\
Non-Obligatory & 12 & 24 & 19 \\
\hline
\end{tabular}

The gravity model or induced-demand model is designed to forecast the total amount of induced traffic for each of the different modes. Gravity models are single-mode in the sense that they apply only to the mode of transport whose traffic generation is to be estimated. The induced traffic is proportional to the variation in the generalized cost, and is highly dependent on the services offered by the new high-speed rail mode in terms of travel time, fares, frequency, comfort, and accessibility to stations.

Analytically,

$$
T_{j}=K \frac{\left(P_{0 p i} \cdot P_{0, j}\right)^{a}\left(W_{i} \cdot W_{j}\right)^{F}}{C_{g i j^{\gamma}}}
$$

where:

$T_{i j} \quad$ is the traffic between zone $i$ and zone $j$

$P_{0 p i}$ and $P_{0 p j}$ are the population of zones $i$ and $j$

$W_{i}$ and $W_{j}$ indicate the income per capita of zones $i$ and $j$

$C_{g i j} \quad$ represents the generalized cost of transport between zone $i$ and zone $j$ 


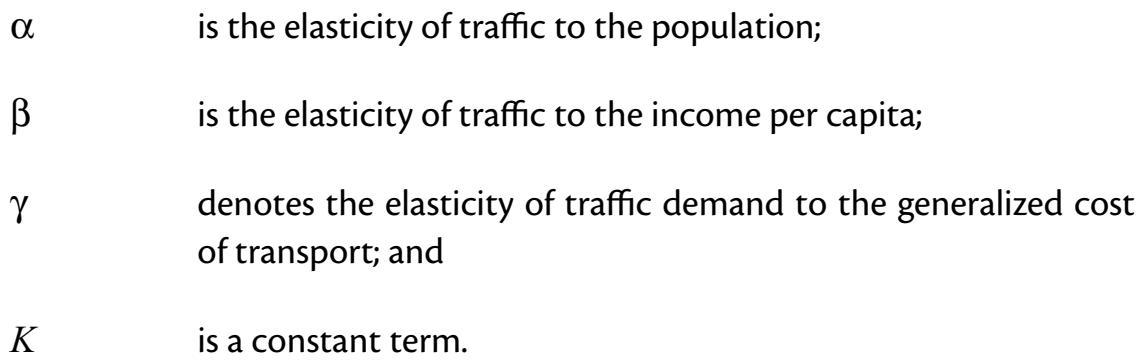

Following a change in the services offered, the variation in traffic $\Delta \mathrm{T}$ is linked to the variation in the generalized cost $\Delta \mathrm{Cg}$ by means of the formula:

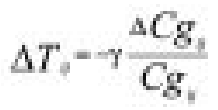

The analysis undertaken in the different Spanish sectors allows us to make the following conclusions:

1. The elasticity of population is close to the unity $(\propto \approx 1)$.

2. The elasticity of the income per capita is close to $0.9(\beta \approx 0.9)$.

3. The elasticity of traffic demand to the generalized cost of transport is $\mathbf{1 . 6}$ for nonbusiness trips and 1.9 for business trips.

The following results have been obtained based on the preceding hypotheses:

- Air traffic captured by the high-speed railway

- Highway traffic capture

- Traffic on conventional railway lines captured

- Traffic generated

- Total
$2.20 \mathrm{M}$ travelers

$0.36 \mathrm{M}$ travelers

$0.57 \mathrm{M}$ travelers

$0.35 \mathrm{M}$ travelers

3.48 $M$ travelers

Thus, the railway will transport 3.48 million travelers, compared to 2 million travelers by airplane $(4.2-2.2 \mathrm{Mt})$, giving rise to a distribution for the means of transport as 64 percent (railway) and 36 percent (airplane). 
On the other hand, the forecasts generated by Iberia claim that start-up of the high-speed railway line will mean a loss of 38 percent in all air traffic on the Madrid-Barcelona route compared to current level of traffic (4.2 million travelers).

According to the Iberia forecast, distribution between the airplane-railway systems would be as follows:

- Airplane

- High-speed railway

- Captured from air transport

- Captured from conventional railways
2.60 $M$ travelers (54.5\%)

$2.17 M$ travelers (45.5\%)

1.60 $M$ travelers

$0.57 \mathrm{M}$ travelers

Without taking into account the traffic that rail will capture from highway and the traffic generated by the railway itself, airplane traffic will have a market share of 54.5 percent with respect to the railway. The inclusion of the two above-mentioned means of transport, which are not considered by lberia (highway $0.36 \mathrm{Mt}$ and newly generated traffic $0.35 \mathrm{Mt}$ ), would thus invert the preponderance of air traffic - railway $(2.88 \mathrm{Mt})$ and airplane $(2.6 \mathrm{Mt})$ - giving rise to a distribution for the various means of transport as 52.5 percent and 47.5 percent, respectively. The results are summarized in Table 6.

\section{Table 6. Forecast of Evolution of Rail-Plane Travelers Modal Distribution in Relation to Madrid-Barcelona with New High-Speed Line}

\begin{tabular}{|l|c|c|c|}
\hline \multirow{2}{*}{ Mode } & \multirow{2}{*}{ At Present } & \multicolumn{2}{|c|}{ Forecast with New High-Speed Line } \\
\cline { 3 - 4 } & $11 \%$ & Author's Estimate & Iberia \\
\hline Railway & $89 \%$ & $63.5 \%$ & $52.5 \%$ \\
Plane & $36.5 \%$ & $47.5 \%$ \\
\hline
\end{tabular}

In conclusion, in the initial stages, it seems reasonable to predict that, given the differences in the existing supply between the Madrid-Seville and Madrid-Barcelona routes, the high-speed railway will not—at least initially_reach a market share of 80 percent with respect to air travel. This is a value that might be estimated from the existing European experience (Figure 3 ) and particularly from the results obtained for the high-speed line between Madrid and Seville. Therefore, we can expect that the impact of the high-speed line between Madrid and Barcelona, 
where a high density of air services already exists, will not be as high as the rest of the high-speed lines in commercial services across Europe today.

At this time, it is not possible to predict to what degree the decrease in air traffic will affect each of the companies currently operating between Madrid and Barcelona. However, it is reasonable to believe that both Air Europa and Span Air will withdraw their services, especially the former, leaving Iberia as the sole airline operating this route.

The results of our analysis with regard to the distribution of the high-speed railway services (64\%) can be compared to a real-life instance of the Paris-London line.

In effect, currently the Eurostar takes 2 hours, 35minutes to complete the route and dictates about 65 percent of the market, compared to 35 percent by air transport services. Air transport between London and Paris (2.8 million passengers in 2003 ) is one of the highest in Europe. Nowadays, there are more than 90 flights per day in either direction between the two cities.

With the high-speed railway services, the percentage of the market using private vehicles currently represents about 16 percent of the total passengers.

\section{Conclusions}

The Madrid-Barcelona route constitutes one of the most heavily-used air routes by passengers in Europe. From 1974 until 1993, there was continuous flight service (air shuttle) which went from transporting 0.9 million passengers to almost 2 million passengers with a single operating airline-Iberia.

The process of liberalizing air transport in 1994 made it possible for two new companies, Air Europa and Span Air, to offer services along the same route. Their entry into the market generated additional air traffic of almost 1 million passengers in the first year. With each of them attracting almost 15 percent of the market share, these companies reduced Iberia's share to 70 percent. 2001 and 2002, Span Air's market share increased considerably, reaching its current share of 21 percent compared to Iberia's share of 64 percent in the same market.

Within the next two years, the entry into commercial service of a high-speed railway line between Madrid and Barcelona will likely cause an alteration in the transport market. Forecasts predict that the railway line will have a market share of around 53 to 63 percent (compared to its current 11\%), thus reducing the airlines' current market share of 89 to 36 to 47 percent. 


\section{References}

European Commission, DG VII.1995. Optimising rail/air intermodality in Europe. López-Pita, A. 2001. Railway and plane in the European transport system. CENIT, Ediciones UPC. ISBN 84.8301-650-8: 102.

López-Pita, A. Airport connections of high-speed lines. CENIT Ediciones UPC. ISBN 84-8301-683-4.

López-Pita, A., and F. Robusté. 2003. The effects of high-speed rail on the reduction of air congestion. Journal of Public Transportation 6, 1:37-52.

López-Pita, A., and F. Robusté. 2003. The Madrid-Barcelona high-speed line. Proceedings of the Institution of Civil Engineers 156: 3-8.

Martin-Cuesta, J. L. 1998. Stratégies commerciales pour l'AVE. Rail International, (Septembre-Octobre): 259-262.

Pavaux, J. 1991. Rail/air complementarity in Europe: The impact of high-speed train services. Institute of Air Transport-Paris. ISBN 2-908537-04-4.

Pérez-Sanz, J. 1995. Le système de la grande vitesse : l'expérience espagnole. Rail International (Aôut-Septembre): 67-70. 


\section{About the Authors}

ANDRÉs López-PITA (andres.lopez-pita@upc.edu) is a professor of railway engineering and director for the Centre for Innovation in Transport (CENIT) at the Technical University of Catalonia. He has several years of research experience in transportation planning and has been a member of the board of directors of Spanish Railways. He has published more than 250 papers in scientific journals and authored more than 20 books.

FRANCESC RobUStÉ (frobuste@upc.edu) received his Ph.D in engineering at the Technical University of Catalonia at Barcelona, a master of science in operations research, and master of engineering in transportation at the University of California at Berkeley. He has been professor of transport since 2002; director of the Civil Engineering School since 2004; and subdirector of research, development, and innovation of the Centre of Innovation in Transport (CENIT) since 2001. His work has appeared in more than 150 publications. 